\title{
The Bank-Specific Factors Affecting the Profitability of Commercial Banks in Bangladesh: A Panel Data Analysis
}

\author{
Khaled Mahmud ${ }^{1}$, Avijit Mallik ${ }^{2}$, Md. Farhan Imtiaz ${ }^{3}$, Dr. Nazia Tabassum ${ }^{4}$ \\ ${ }^{1}$ Assistant Professor, Institute of Business Administration, University of Dhaka \\ ${ }^{2}$ Lecturer, United International University, Bangladesh \\ ${ }^{3}$ Lecturer, Institute of Business Administration, University of Dhaka \\ ${ }^{4}$ Associate Professor, Department of Agribusiness and Marketing, Bangladesh Agricultural University

\begin{abstract}
The objective of this paper is to identify the bank specific variables that affect the profitability of commercial banks of Bangladesh. A total of 15 commercial banks were taken \& their financial reports were analyze from 2003-2013. The study used return on asset as the dependent variable \& bank specific variables like capital adequacy ratio, gearing ratio (risk), liquidity, non-performing loan ratio, operating expense ratio \& bank size as independent variables. Prais-Winsten correlated panels corrected standard errors (PCSEs) model was employed which removes any autocorrelation \& heteroskedasticity problem automatically for the panel data. The results indicated that size, operating expense, gearing ratio \& capital were found to be important variables that affect the bank profitability of Bangladesh. Other two variables were not important determinants for Bangladeshi commercial banks. Capital shows positive relation to bank profitability but other three statistically significant variables showed negative relation to performance. Empirical results suggests that adequate capital, low risk, efficient expense management \& rightsizing lead to greater performance and profitability for Bangladeshi bank industry.
\end{abstract}

Keywords: Bank profitability, Bangladesh, commercial banks, panel data analysis.

\section{INTRODUCTION}

This paper investigates the factors that influence the profitability of commercial banks of Bangladesh. These factors are crucial in determining the bank profitability .Banking sector plays a pivotal role as it ensures efficient flow of financial resources from savers to borrowers. Since banks work as a financial intermediary of financial system, efficiency \& smooth performance lead to economic growth. Therefore sound performance of commercial banks is what a country needs for healthy economic growth.

By contrast, poor performance of banks can cause problems like bank failure which can demolish the confidence in banking system \& hence cause economic slowdown.

Banking sector in Bangladesh is highly competitive. Recently this sector is going through critical situations. The major trend has been lower growth in credit, increasing NPL's\& lower interest rate due to high cost of capital which altogether increase the risk \& hence reduce the profitability of this sector. Since commercial banks are profit maximizer, such risks \& inefficiencies can lead to a lowering of profit which is a major concern for both managers \& investors. Due to limited investment opportunity \& bearish stock market in Bangladesh, investors are more concern about the performance of banks especially commercial ones. Hence this study is expected to provide an important insight about what factors lead to the performance of banks \& how performance of Bangladeshi commercial banks can be improved.

The second section of our study provides empirical evidence regarding previous studies. Third section deals with research design, model \& the fourth section discusses the empirical findings \& consequences of the results.

\section{LITERATURE REVIEW}

There are a number of studies which tested the factors that affected the profitability of banks. The mostly used proxy for profitability are ROA \& ROE. In our study we considered ROA as a dependent variable indicating profitability. 
Miller conducted a study on USA banks from 1985-1990 \& found size of the banks to be inversely related to profitability. The study suggested that the bigger sized banks suffer from management inefficiency which might lead to a slowdown of profitability.

Kosmidon (2008) had quite different findings as he found size to be positively related to profitability. Chirwa (2003) found CAR \& ROC to be inversely related. Asset utilization \& operating expenses were found to be significantly related to ROA. Akhtar, Ali, Sadaqat(2011) used panel data from 20062009 for Pakistani banks \& found gearing ratio, NPL \& asset management to be significantly affecting the profitability of Pakistani conventional banks.

Khrawish (2011) conducted a study on Jordanian commercial banks over 2000-10 and found that ROA and size, leverage, capital adequacy ratio, net interest margin and expense management efficiency is positively related while ROA \& GDP, inflation are negatively related. Macit (2011) conducted a research on Tarkish commercial banks and observed that NPL ratio is negatively related to both ROA \& ROE. Riaz (2013) conducted a study on bank profitability over $2006-2010$ \& found that credit risk \& interest rate determine the profitability of Pakistani banks.

Obamuyi (2013) conducted a study on 20 commercial banks of Nigeria over 2006-12 \& employed fixed effect model to determine the relationship of different bank specific \& macro-economic variable. The study reported that bank capital, size, interest income \& expense management efficiency and favorable economic conditions contribute to higher bank performance and growth. Camilleri (2005) found that size was positively related to the profitability of banking industry of Malta. Islam (2010) examined the impact of bank sizes on bank profit performances using OLS. The study found that bank sizes and bank profitability were positively related in Bangladesh.

Samad (2015) examines the impact of both bank specific and macroeconomic variables that affect profitability of Bangladesh banking industry. The study was conducted on a panel data set consisting 42 Bangladeshi commercial banks. The study used bank specific variables such as bank financial risk, bank operational efficiency, and bank sizes as well as macroeconomic variables such as economic growth are examined to estimate their impact of bank profits. The paper indicates that factors such as loan-deposit ratio, loan-loss provision to total assets, equity capital to total assets, and operating expenses to total assets are significant factors. Bank sizes and macroeconomic variable show no impact on profits.

\section{RESEARCH METHODOLOGY}

The study examined the factors that are specific to bank profitability for commercial banks of Bangladesh. Since the data set is panel in nature, correlated panels corrected standard errors (PCSEs) model has been used for analyzing the data. The relationship between Return on Asset (ROA) \& bank specific determinants have been shown here. Portrayal of both the dependent $\&$ independent variables is shown below with their proxies in Table 3.1.

Table3.1. Variable, their Proxies and Symbols

\begin{tabular}{|l|l|l|}
\hline Symbols & Variables & Proxies \\
\hline $\boldsymbol{Y}$ & ROA (Return On Asset) & Net Profit Before Tax/Total Assets \\
\hline \multicolumn{2}{|l|}{ Explanatory Variables } & Logarithm of Total Assets \\
\hline $\boldsymbol{X} \mathbf{1}$ & Bank's Size & Total Debts/Equity \\
\hline $\boldsymbol{X} \mathbf{2}$ & Gearing Ratio & Non-Performing Loans/Total Loans \\
\hline $\boldsymbol{X} \mathbf{3}$ & NPLs Ratio & Liquid assets/(deposit+borrowings) \\
\hline $\boldsymbol{X} \mathbf{4}$ & Liquidity Ratio & Total Operating Expenses/Total Assets \\
\hline $\boldsymbol{X} \mathbf{5}$ & Operating Expense Ratio & Tier 1 Capital + Tier 2 Capital / Risk Weighted Assets \\
\hline $\boldsymbol{X} \mathbf{6}$ & Capital Adequacy Ratio &
\end{tabular}

\subsection{Data Collection}

Financial data is obtained from the annual reports of 15 commercial banks for the period of 20032013. Data have been collected from each company's respective websites. The multi-variant regression model will be used to test the significance of variables on profitability of commercial banks. 


\subsection{Profitability Measures}

Return of assets (ROA) is mostly used because of its ability for effective and efficient management in utilizing the firm's asset to generate maximum profit. The return on asset (ROA) is a substantial performance measure because it is directly related to the profitability of banks (Kosmidou, 2008; Sufian\&Habibullah, 2009). The higher the value of ROA, the greater the profitability of banks.

Following equation is derived for multi-variant regression analysis.

$$
\begin{aligned}
& \mathbf{R O A}_{\mathbf{i}, \mathbf{t}}=\boldsymbol{\alpha}_{\mathbf{i}, \mathbf{t}}+\boldsymbol{\beta}_{\mathbf{1}} \mathbf{S I Z E}_{\mathbf{i}, \mathbf{t}}+\boldsymbol{\beta}_{2} \mathbf{G R}_{\mathbf{i}, \mathbf{t}}+\boldsymbol{\beta}_{\mathbf{3}} \mathbf{N P L} \mathbf{L}_{\mathbf{i}, \mathbf{t}}+\boldsymbol{\beta}_{\mathbf{4}} \mathbf{L} \mathbf{I} \mathbf{Q}_{\mathbf{i}, \mathbf{t}}+\boldsymbol{\beta}_{\mathbf{5}} \mathbf{O} \mathbf{E}_{\mathbf{i}, \mathbf{t}}+\boldsymbol{\beta}_{\mathbf{6}} \mathbf{C A R}_{\mathbf{i}, \mathbf{t}}+\boldsymbol{\epsilon}_{\mathbf{i}, \mathbf{t}} \\
& \text { Here, } \alpha=\text { intercept } \\
& \beta_{1,} \beta_{2,} \beta_{3,} \beta_{4,} \beta_{5,} \beta_{6} \text { are coefficients of X1, X2, X3, X4, X5 and X6 respectively } \\
& €=\text { error term } \\
& \mathrm{i}=\text { firm } 1 \text { to } 15, \\
& \mathrm{t}=\text { year } 1 \text { to year } 11
\end{aligned}
$$

\subsection{Bank-Specific Factors}

a) Bank Size: The bank size is an important determinant of profitability. It can influence the banks operations internally in either way. The positive relation of bank size with ROA indicates that the bank has been able to achieve economies of scale which in affect reduces the costs of operation \& hence helps to achieve greater profitability. A negative relation on the other hand indicates a diseconomies of scale (Chirwa, 2003; Naceur\&Goaied, 2001; Kosmidou, 2008).

b) Gearing Ratio: Gearing ratio demonstrates what portion of debt \& equity the banks are using to finance its asset. It is measured by the ratio of debt to equity. Relatively higher gearing ratio indicates higher liquidity risk as the debt holders might require more rate of return. It represents high liquidity risk which might lower the profitability. This is a very significant determinant of credit position as discussed by previous study (Barnhill, Papapanagiotou, \& Schumacher, 2002).

c) Non-performing Loan Ratio: Non-Performing loan ratio measures loans in default. Boudriga, Taktak and Jellouli (2009) found that the profitability of banks is negatively related to the amount of Non-Performing Loans (NPLs). The greater the amount of classified loan as a percentage of total loan, the lower the profitability of banks.

d) Liquidity: There is a trade-off between liquidity and profitability. Liquid assets work as a safeguard against the deposits which might require on demand payment. So greater liquidity means lesser risk but it also reduces the funds available for lending. So higher liquidity indicates lower profitability. So a negative relationship exists between these two.

e) Operating Expense Ratio: We will use total operating expenses divided by total assets as proxy for measuring the operating efficiency (Tarawneh, 2006). Efficient management leads to a lowering of operating expanse which in turns increases the profitability of firm. An inverse relationship is expected between ROA \& operating expense ratio.

f) Capital Adequacy Ratio (CAR): Capital adequacy ratio is a measure of a bank's net worth. It indicates the amount of fund that are available to safeguard against adverse development. The relation between ROA \& CAR is unpredictable (sharma\&gounder 2005). While some research suggest that the relationship is negative other research suggests a positive relationship.

\section{EMPIRICAL RESULTS}

\subsection{Descriptive and Correlation Statistics}

Descriptive statistics for all variables under study are reported below. The table shows the values for mean and standard deviation. 
Khaled Mahmud et al.

Table4.1. Descriptive Statistics

\begin{tabular}{|l|l|l|}
\hline Descriptive Statistics & Mean & Std. Deviation \\
\hline Variables & 0.0447 & 0.0734308 \\
\hline Return on Assets (ROA) & 24.44 & 1.62 \\
\hline Bank's Size & 10.96769 & 7.4039 \\
\hline Gearing Ratio & 0.064 & 0.1235 \\
\hline NPLs Ratio & 0.166606 & 0.2132816 \\
\hline Liquidity & $4.18 \mathrm{E}+08$ & $9.25 \mathrm{E}+08$ \\
\hline Operating Expense Ratio & 0.06812 & 0.2775 \\
\hline Capital Adequacy Ratio & & \\
\hline
\end{tabular}

Table 4.2 reports the correlation matrix for all explanatory variables. The results of correlation coefficients show that none of the independent variable is highly correlated other independent variable. The matrix show that the relation of independent variables is not well-built, so the problem of multi co linearity is absent for this data.

Table4.2. Correlation Coefficients

\begin{tabular}{|c|c|c|c|c|c|c|}
\hline \multicolumn{7}{|c|}{ Correlation Coefficients } \\
\hline \multirow[t]{2}{*}{ Variables } & \multirow{2}{*}{$\begin{array}{l}\text { Bank's } \\
\text { Size }\end{array}$} & \multirow{2}{*}{$\begin{array}{l}\text { Gearing } \\
\text { Ratio }\end{array}$} & NPLS & \multirow[t]{2}{*}{ Liquidity } & \multirow{2}{*}{$\begin{array}{l}\text { Operating } \\
\text { Expense Ratio }\end{array}$} & \multirow{2}{*}{$\begin{array}{l}\text { Capital } \\
\text { Adequacy Ratio }\end{array}$} \\
\hline & & & Ratio & & & \\
\hline Bank's Size & 1 & 0.0872 & -0.1283 & -0.064 & -0.0312 & -0.0809 \\
\hline Gearing Ratio & & 1 & -0.3299 & 0.1223 & -0.0443 & -0.3062 \\
\hline NPLs Ratio & & & 1 & -0.0164 & 0.105 & -0.4944 \\
\hline Liquidity & & & & 1 & 0.188 & 0.0673 \\
\hline $\begin{array}{l}\text { Operating } \\
\text { Expense Ratio }\end{array}$ & & & & & 1 & 0.0615 \\
\hline $\begin{array}{l}\text { Capital } \\
\text { Adequacy Ratio }\end{array}$ & & & & & & 1 \\
\hline
\end{tabular}

\subsection{Test of Multicollinearity}

In order to check the presence of multicolinearity problem in the data set, we have gone through VIF test. The results are shown below:

Table4.3. Variable inflator factor $(V I F)$ and tolerance level

\begin{tabular}{|l|l|l|}
\hline Variable & $\boldsymbol{V I F}$ & $\mathbf{I} \boldsymbol{V I F}$ \\
\hline Size & 1.03 & 0.975 \\
\hline Gearing Ratio & 1.18 & 0.848 \\
\hline NPL Ratio & 1.42 & 0.703 \\
\hline Liquidity & 1.07 & 0.937 \\
\hline Operating Expense Ratio & 1.05 & 0.952 \\
\hline Capital Adequacy Ratio & 1.37 & 0.72 \\
\hline MEAN & 1.19 & 0.84 \\
\hline
\end{tabular}

The table shows that the VIF for each independent variable is less than 10 (cut off VIF) \& so is the mean VIF. Moreover none of the tolerance value is less than .10 (cut off tolerance statistic). So our model is free from the problem of multicollinearity.

\subsection{The test of Heteroskedasticity}

In order to test the problem of Heteroskedasticity, we used the breuschpegan test. The test examines whether the error variance is constant. The results are:

\section{Breusch-Pagan / Cook-Weisberg test for heteroskedasticity}

$\mathrm{H}_{0}$ : Constant variance

Variables: fitted values of ROA

$$
\begin{gathered}
\operatorname{chi}^{2}(1)=9.61 \\
\text { Prob>chi }=0.0019
\end{gathered}
$$


The Bank-Specific Factors Affecting the Profitability of Commercial Banks in Bangladesh: A Panel Data Analysis

The $\mathrm{chi}^{2}$ value has a probability of $0.19 \%$ which is less that $5 \%$ level of significance. So we reject the null hypothesis of constant variance. So there is heteroskedasticity problem in this regression model.

\subsection{Test of Autocorrelation}

There may be autocorrelation problem in the data set due to presence of time element. We derived the rho value for this model the summery result is given below:

\begin{tabular}{|c|c|c|c|c|}
\hline Value of Rho ( $\rho)$ & $\begin{array}{l}\text { Durbin } \\
\text { Watson } \\
\text { statistic } \\
d=2(1-\rho)\end{array}$ & $\begin{array}{l}\text { Critical DW Value for } \\
K=6, n=165 \text { Lower } \\
\text { tail @1\% level }\end{array}$ & $\begin{array}{l}\text { Critical DW Value for } \\
K=6, n=165 \text { upper tail @ } \\
1 \% \text { level }\end{array}$ & Autocorrelation \\
\hline 0.6096057 & 0.78 & 1.44 & 1.65 & Present\& positive \\
\hline
\end{tabular}

The calculated value for DW test is 0.78 which is less than the lower tail value of 1.44 . So we reject the null hypothesis of no autocorrelation. So there exists the problem of autocorrelation.

\subsection{Model Specification\& Results}

The diagnosis reveals that the model has no multicollinearity problem but the data set is both heteroskedastic and auto correlated. So we have decided to go for PCSE model which automatically correct heteroskedasticitty\& autocorrelation problem.

\section{Prais-Winsten regression, correlated panels corrected standard errors (PCSEs)}

$$
\begin{aligned}
& \text { R-squared }=0.2474 \\
& \text { Wald } \operatorname{chi}^{2}(5)=42.92 \\
& \text { Estimated coefficients }=7 \\
& \text { Prob }>\text { chi }^{2}=0.0000
\end{aligned}
$$

Table4.4. Regression output

\begin{tabular}{|l|l|l|l|l|}
\hline ROA & Coefficient & Std. Err. & $\boldsymbol{z}>|z|$ \\
\hline Capital Adequacy Ratio & $\mathbf{0 . 0 7 6 9 0 9 6 *}$ & 0.0151416 & 5.08 & 0.000 \\
\hline Liquidity Ratio & 0.0099462 & 0.0121165 & 0.82 & 0.412 \\
\hline NPL Ratio & -0.0384169 & 0.0396888 & -0.97 & 0.333 \\
\hline Size & $\mathbf{- 0 . 0 0 8 2 0 5 2 *}$ & 0.0033678 & -2.44 & 0.015 \\
\hline Operating Expense Ratio & $\mathbf{- 1 . 7 4 E - 1 1 *}$ & $8.74 \mathrm{E}-12$ & -1.99 & 0.046 \\
\hline Gearing Ratio & $\mathbf{- 0 . 0 0 0 8 1 0 2 *}$ & 0.0003934 & -2.06 & 0.039 \\
\hline _constant & 0.222274 & 0.0842581 & 2.64 & 0.008 \\
\hline
\end{tabular}

*Significant at $5 \%$ level

The regression output shows that the overall multiple regression is statistically significant as the chi squared value of 42.92 gives a level of significance of $0 \%$ which is less than $5 \%$. R squared value shows that only $24.74 \%$ of variation in ROA has been explained by the bank specific independent variables. At 5\% level of significance it is observed that capital adequacy ratio, size of banks, operating expense \& gearing ratio is found to be statistically significant. For commercial banks of Bangladesh, CAR is found to be a significant determinant of profitability. CAR shows a positive relation to profitability which means a higher level of core \& supplementary capital provides adequate safeguard against potential bank failure which in turn reduces the risk. High CAR also provides signal to market that the future prospect of the bank is good .It provides a positive signal about market value $\&$ enhance financial performance of the banks. This finding is consistent with Ommeren(2011), Berger (1995) and Trujillo- Ponce (2012).

The model shows that liquidity is not an important variable for Bangladeshi commercial banks' profitability. Moreover liquidity shows wrong sign also. NPL ratio is not statistically significant at 5\% level but it shows expected sign in relation to profitability. A negative relation of NPL ratio to profitability implies that greater classified or under performing loan deteriorates the bank profitability for commercial banks in Bangladesh. The size variable is a statistically significant variable that negatively effects the profitability. It implies that the due to management inefficiencies the large banks are facing diseconomies of scale which reduces the performance. This finding is consistent with 
Chirwa (2003).Managerial implication is that the commercial bank managers should go for rightsizing of the firms in order to restore the profitability.

The operating expense ratio is statistically significant factors for private commercial banks (PCB) of Bangladesh. It is inversely related to profitability as higher operating expense leads to poor management of operations \& lowers the profitability. This finding is consistent with Tarawneh (2006). Gearing ratio implies the risk from leverage. This variable is also found statistically significant. It is negatively related to profitability as greater leverage leads to higher risk which reduces the profitability of private commercial banks (PCBs) as depositors demand higher rate which increases the cost of fund. So in a nutshell, for private commercial banks of Bangladesh, CAR ratio, gearing ratio, size \& operating expense ratio significantly affect the profitability while NPL ratio \&liquidity are not the important determinants.

\section{SUMMERY AND CONCLUSION}

The objective of this paper was to identify the bank specific factors that affect the profitability of private commercial banks of Bangladesh. The study was conducted on 15 PCB of Bangladesh over 11 years from 2003 to 2013. The analysis shows that size, capital adequacy, operating expense ratio \& gearing ratio (risk) were found to be statistically significant. While size, operating expense ratio \& gearing ratio (risk) affect the bank profitability negatively, CAR affects the bank profitability positively. Other two bank specific variables i.e. liquidity\& NPL ratio are not important variables for bank profitability of Bangladesh. Major implication of this study is that relatively smaller sized \& well managed banks which have adequate capital \& lower gearing ratio are empirically found to have greater profitability. Moreover, large firms are more likely to face diseconomies scale which might think to right size itself to become more profitable. The study did not include macro variables which might affect the banking sector profitability. So there is scope for further investigation for the banking sector profitability of Bangladesh. Nevertheless we believe that this study shall provide the regulators, owners, managers, depositors \& other concerned parties an important insight about bank profitability $\&$ enhance the performance thereby.

\section{REFERENCES}

Akhtar, M. F., Ali, K., \&Sadaqat, S. (2011). Liquidity Risk Management: A comparative study between Conventional and Islamic Banks of Pakistan. "Interdisciplinary Journal of Research in Business", 1(1), 35-44.

Alexiou, C., \&Sofoklis, V. (2009). Determinants of Bank Profitability: Evidence from the Greek Banking Sector. Economic Annals, LIV No. 182, 93-118.

Ali, K., Akhtar, M. F., \& Ahmed, H. Z. (2011). Bank-Specific and Macroeconomic Indicators of Profitability - Empirical Evidence from the Commercial Banks of Pakistan. "International Journal of Business and Social Science", 2(6), 235-242.

Barnhill, T. M, Papapanagiotou, J.P. \& Schumacher, L. (2002). "Measuring Integrated Market and Credit Risk in Bank Portfolios: An Application to a Set of Hypothetical Banks Operating in South Africa". Financial Markets Institutions \& Instruments, 11 (5).

Chirwa, E. W. (2003). Determinants of commercial banks in Malawi: a cointegration approach. Applied Financial Economics, 13, 565-571.

Khrawish, H. A. (2011). Determinants of Commercial Banks Performance: Evidence from Jordan. International Research Journal of Finance and Economics, 81, 148-159.

Kosmidou, K. (2008). The determinants of banks' profits in Greece during the period of EU financial integration. Managerial Finance, 34 (3), 146-159.

Macit, F. (2011). Bank Specific and Macroeconomic Determinants of Profitability: Evidence from Participation Banks in Turkey. Economics Bulletin, 32(1).

Miller, S. M., \&Noulas, A. G. (1997). Portfolio mix and large-bank profitability in the USA. Applied Economics, 24 (4), $505-512$.

Obamuyi, T. M. (2012). Financial Development and Economic Growth in Emerging Markets: The Nigerian Experience. Indian Journal of Finance, 6(4), 16-27.

Ommeren, S. V. (2011). An Examination of the Determinants of Banks' Profitability in the European Banking Sector, An Unpublished M. Sc. Thesis, Department of Accounting and Finance, Erasmus School of Economics Erasmus University, Rotterdam. 
Riaz, S. (2013). Profitability Determinants of Commercial banks in Pakistan, Proceedings of 6th International Business and social Sciences Research Conference, 3-4 January, Dubai, and UAE. Available at: http://www.wbiconpro.com/603-Samina.pdf.

Sadaqat, M. S., Akhtar, M. F., \& Ali, K. (2011). An Analysis on the Performance of IPO - A Study on the Karachi Stock Exchange of Pakistan. "International Journal of Business and Social Science", 2(6), 275-285.

Siddiqui, A. (2008). "Financial contracts, risk and performance of Islamic banking". Managerial Finance, 34 (10), 680-694.

Sufian, F., \&Habibullah, M. S. (2009). Bank Specific and Macroeconomic Determinants of Bank Profitability: Empirical Evidence from the China Banking Sector. Front. Econ. China, 4 (2), 274291.

Trujillo-Ponce, A.(2012). What Determines the Profitability of Banks? Evidence from Spain, Accounting and Finance, 53(2), Available at: www.aeca.es/pub/on_line/comunicaciones_ xvicongresoaeca/.../75b.pdf

\section{Appendix}

\section{List of commercial banks:}

1. Al arafaIslami Bank Limited

2. Bank Asia Limited

3. The city Bank Limited

4. National Credit \& Commerce Bank

5. Prime Bank Limited

6. Southeast Bank Limited

7. Eastern Bank Limited

8. Dhaka Bank Limited

9. Mercantile Bank Limited

10. Standard Bank Limited

11. United Commercial Bank Limited

12. Social Islamic Bank Limited

13. EXIM Bank Limited

14. United Commercial Bank Limited

15. Mutual Trust Bank Limited

\section{AUTHORS' BIOGRAPHY}

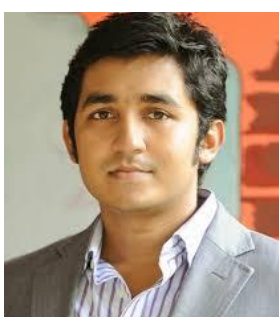

Khaled Mahmud, is Assistant Professor at the Institute of Business Administration (IBA), University of Dhaka. He is a Fulbright business fellow and received his MBA from Bentley University, Massachusetts, USA. Prior to that, he completed his Masters of Business Administration in marketing from Institute of Business Administration (IBA), University of Dhaka. He completed his undergraduation in Computer Science and Engineering (CSE) from Bangladesh University of Engineering and Technology (BUET).

He is currently working as strategic consultant at access to Information project of the Prime Minister's Office, Bangladesh. He worked as consultant for Bangladesh Police in association with UNDP to formulate the strategic plan 2012-14 for Bangladesh Police. Prior to joining IBA as a fulltime faculty, he worked in Standard Chartered Bank as Assistant Manager. He has a very diversified research portfolio. He published articles related to IT, marketing, finance, human resources, business strategy and social sciences. 


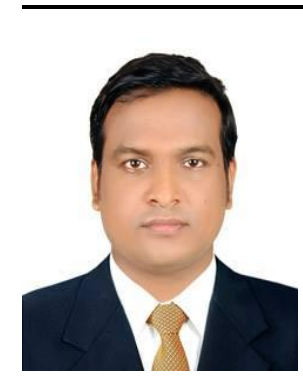

Avijit Mallik, is Lecturer at United International University (UIU), Dhaka. He received MBA degree from Institute of Business Administration (IBA), University of Dhaka. Securing the highest CGPA in his batch. He was valedictorian of his batch and received gold medal for his academic excellence. $\mathrm{He}$ also has another MBA in finance from faculty of business studies of University of Dhaka. Prior to that he completed his BBA in finance from the same university.

He is currently working as the principal investigator of a research project funded by UIU faculty research grant authority. He is also working as an advisor of United International University Finance Forum. He has published article on capital structure of Bangladeshi firms. He has research interest in financial econometrics, market efficiency, behavioral finance, portfolio management, asset pricing models and he is looking forward to working on these research areas in future.

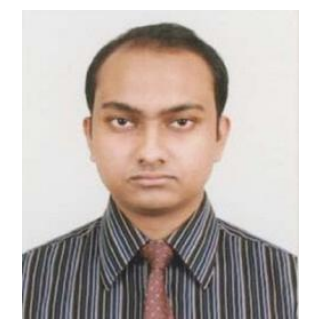

Md. Farhan Imtiaz, is a lecturer at the Institute of Business Administration (IBA), University of Dhaka. Once a pharmacist, Imtiaz planned to change his career track and received business education from IBA, the pioneer institution that provides business education in Bangladesh. He did his MBA from IBA, University of Dhaka. He was the valedictorian and received a gold medal for being the topper of his batch. Before that, he completed his Bachelor of Pharmacy degree from North South University, Dhaka. After completing MBA, he worked for a local commercial bank named Prime Bank Limited as a Management Trainee Officer. Then he moved to teaching at IBA and conducting Finance major courses and other fundamental courses. $\mathrm{He}$ has a dedicated research oriented academician. He has publication in the area of pharmaceutical sciences, social sciences, capital market, capital budgeting etc.

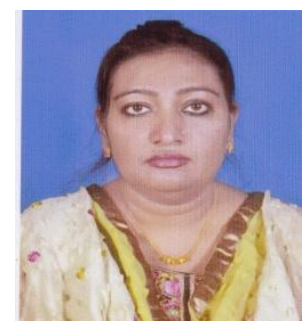

Dr. Nazia Tabassum, is an associate professor at the Department of Agribusiness and Marketing, Bangladesh Agricultural University, Mymensingh, Bangladesh. She completed her B.Sc.in Agricultural Economics and M.Sc. in Agricultural Economics (Marketing) from Bangladesh Agricultural University, Mymensingh, Bangladesh. She joined as a lecturer in the same university in the year 2007. She received her Ph.D degree from Chungnam National University, Korea. After having done her Ph.D she came back and now she is enlightening the students with the knowledge she has acquired from Chungnam National University. Her area of research is agricultural sciences, economics, marketing and finance. 